\title{
PERBEDAAN KARAKTERISTIK KELUARGA DENGAN KEJADIAN GIZI KURANG PADA BALITA SUKU BAJO DAN NON BAJO DI WILAYAH PESISIR KOTA KENDARI
}

\author{
Irma $^{1)}$, Swaidatul Masluhiya $\mathbf{A F}^{2)}$ \\ ${ }^{1)}$ Fakultas Kesehatan Masyarakat, Universitas Haluoleo, Kendari \\ ${ }^{2)}$ Fakultas Ilmu Kesehatan Universitas Tribhuwana Tunggadewi, Malang \\ E-mail: irmankedtrop15@gmail.com; swaee.af@gmail.com
}

\begin{abstract}
Malnutrition is a problem that occurs globally, especially in developing countries, including Indonesia. Malnutrition in todllers influenced by various factors such as socio-economic factors, sanitation, behavior and infectious diseases. The purpose of this study to know differences family characteristics (family income, mother's knowledge and parenting) with the incidence of malnutrition in the Bajo and non-Bajo tribe toddlers. This research is a quantitative type study with a comparative design, with a population of all Bajo and non-Bajo tribe toddlers who experience malnutrition in the coastal area of Kendari City. A sample of 82 people were taken with the Simple Random Sampling technique and the mother of toddlers as respondents. The research instrument used was a questionnaire. Furthermore, the data collected has been analyzed statistically by the Independent Sample $t$ Test. The results of this study indicate that there is a significant difference between maternal knowledge and parenting with the incidence of malnutrition in Bajo and non-Bajo tribe toddlers and there is no difference in family income with the incidence of malnutrition in Bajo and non-Bajo tribal toddlers.
\end{abstract}

Keywords: Toddlers; Malnutrition; Bajo and non-Bajo Tribe.

\begin{abstract}
ABSTRAK
Gizi kurang merupakan masalah yang terjadi secara global terutama pada negara - negara berkembang termasuk Indonesia. Gizi kurang pada balita dipengaruhi oleh berbagai faktor seperti faktor sosial ekonomi, sanitasi, perilaku dan penyakit infeksi. Tujuan penelitian ini untuk mengetahui perbedaan karakteristik keluarga (pendapatan keluarga, pengetahuan ibu dan pola asuh) dengan kejadian gizi kurang pada balita suku bajo dan non bajo. Penelitian ini merupakan penelitian kuantitatif dengan desain komparatif, dengan populasi seluruh balita suku bajo dan non bajo yang mengalami gizi kurang yang ada di wilayah pesisir Kota
\end{abstract}

Cara mengutip: Irma \& Masluhiya AF, Swaidatul. (2020). Perbedaan Karakteristik Keluarga dengan Kejadian Gizi Kurang pada Balita Suku Bajo dan Non Bajo di Wilayah Pesisir Kota Kendari. Care:Jurnal Ilmiah Ilmu Kesehatan, 8(1), 74-83 
Kendari. Sampel sebanyak 82 orang yang diambil dengan teknik Simple Random Sampling dan ibu balita sebagai responden. Instrumen penelitian yang digunakan adalah kuesioner. Selanjutnya data yang sudah terkumpul dianalisis secara statistik dengan uji Indepndent Sample $t$ Test. Hasil penelitian ini menunjukkan bahwa ada perbedaan yang singnifikan antara pengetahuan ibu dan pola asuh dengan kejadian gizi kurang pada balita suku bajo dan non bajo dan tidak ada perbedaan pendapatan keluarga dengan kejadian gizi kurang pada balita suku bajo dan non bajo.

Kata Kunci : Balita; Gizi kurang; Suku bajo dan Non bajo.

\section{PENDAHULUAN}

Balita merupakan kelompok usia yang rentan dengan berbagai permasalahan kesehatan termasuk masalah gizi (Lorensa et al., 2018). Faktor - faktor penyebab gizi kurang cukup banyak diantaranya faktor makanan dan penyakit infeksi yang mungkin diderita anak, faktor ketahanan pangan dikeluarga, pola pengasuhan anak, pelayanan kesehatan dan kesehatan lingkungan (Harmiyanti \& Rahman N., 2017). Karakteristik keluarga seperti pendidikan orang tua, pengetahuan, pekerjaan dan pendapatan keluarga merupakan bagian terpenting dalam menjamin ketahanan pangan keluarga. Keluarga dengan tingkat pendidikan dan pengetahaun yang lebih baik akan mudah menerima dan memahami sebuah informasi, termasuk informasi tentang kesehatan seperti perbaikan gizi.

Kondisi demografi masyarakat pada wilayah pesisir Kecamatan Nambo Kota Kendari dari sisi pendidikan masih tergolong rendah. Dimana sebagian besar masyarakatnya baik suku bajo maupun non bajo memiliki tingkat pendidikan yang tergolong masih rendah. Dari 3271 wanita dewasa di Kecamatan Nambo hanya sebanyak 496 orang $(15,16 \%)$ yang memiliki pendidikan setingkat SMA dan Perguruan Tinggi dan sisanya hanya setingkat SD dan SMP serta pada suku bajo sebagian besar tidak pernah menduduki pendidikan formal yaitu dari 132 hanya 47 orang $(35,6 \%)$ yang pernah sekolah dan tamat SD dan SMP sedangkan sebanyak 85 orang $(64,4 \%)$ tidak tamat SD dan SM serta pernah menduduki pendidikan formal (Profil Kecamatan Nambo, 2019).

Rendahnya tingkat pendidikan bagi masyarakat pesisir Kecamatan Nambo khususnya suku bajo ini cukup memprihatinkan karena akan mempengaruhi tingat pengetahuan mereka dalam berbagai hal termasuk masalah kesehatan. Berdasarkan survei pendahuluan dilokasi penelitian ditemukan bahwa masyarakat pesisir di 
Care: Jurnal Ilmiah Ilmu Kesehatan Vol .8, No.1, 2020, hal 74-83

Kecamatan Nambo baik suku bajo maupun non bajo memiliki kebiasaan kaum ibu - ibu ikut membantu suami dalam mecari nafkah atau ikut bekerja baik sebagai pelaut, pedagang atupun buruh bangunan. Kebiasaan ini menjadikan ibu - ibu tidak sepenuhnya mengasuh sendiri anak balitanya dalam waktu 24 jam. Kebiasaan ibu menitipkan anaknya yang masih balita pada neneknya atau saudara anaknya yang lebih tua mempengaruhi pola konsumsi dan pemenuhan nutrisi bagi balita menjadi terganggu karena pemeberian makannya tida tepat waktu.

Kasus gizi kurang pada balita di Kota Kendari pada tahun 2016 sebesar 705 $(3,8 \%)$ balita yang mengalami gizi kurang, kemudian menurun di tahun 2017 sebesar $620(3,1 \%)$ balita gizikurang. Data tahun 2017 tercatat sebanyak $545(2,7 \%)$ balita mengalami gizi kurang di Kota Kendari (Dinas Keshatan Kendari, 2017). Situasi ini menarik untuk diteliti lebih jauh sehubungan dengan tingginya angka gizi kurang pada balita di wilayah pesisir kecamatan Nambo Kota Kendari baik pada suku bajo maupun pada suku non bajo. Status gizi balita di Puskesmas Nambo, sebagai puskesmas yang berada di wilayah pesisir kecamatan Nambo Kota Kendari berdasarkan data Dinas
Kesehatan Kota Kendari tahun 2012 menyebutkan bahwa pada tahun 2010 terdapat kasus gizi buruk berjumlah 252 kasus (1,3\%), gizi kurang berjumlah 705 kasus (3,8\%), Situasi inilah yang mendasari peneliti untuk melakukan penelitian dengan judul "Perbedaan Karakteristik Keluarga dengan Kejadian Gizi Kurang pada Balita Suku Bajo Dan Non Bajo di Wilayah Pesisir Kota Kendari”.

\section{METODE PENELITIAN}

Penelitian ini merupakan penelitian kuantitatif dengan desain komparatif yang dilaksanakan pada bulan Agustus sampai dengan Oktober 2019. Populasi penelitian ini adalah seluruh pasangan ibu dan balita baik suku bajo maupun non bajo dengan kejadian gizi kurang yang ada di wilayah pesisir Kota Kendari dengan sampel sebanyak 82 orang yang terdiri dari kelompok suku bajo dan non bajo masing - masing 41 orang balita dan ibunya sebagai responden yang ambil secara teknik simple random sampling (Nasir, Abd. Murith, Abdul. deputri, 2011). Variabel bebas dalam penelitian ini meliputi karakteristik keluarga (pendapatan keluarga tingkat pengetahuan ibu dan pola asuh) dan variabel terikatnya adalah gizi kurang. Alat pengumpul data untuk mengetahui pendapatan keluarga, tingkat 
pengetahuan,dan pola asuh adalah kuesioner dan data tentang status gizi balita diperoleh di puskesmas Nambo. Analisis data dilakukan secara bertahap yaitu univariat untuk mendeskripsikan masing - masing variabel yang diteliti dan analisis bivariat dengan Independent Sample t Test untuk melihat perbedaan karakteristik keluarga dengan kejadian gizi kurang pada balita suku bajo dan non bajo di wilayah pesisir kecamatan Nambo Kota Kendari. Data yang sudah diolah dan dianalisis disajikan dalam bentuk tabel disertai dengan narasi.

\section{HASIL}

Analisisdata dilakukan secara bertahap yaitu analisis univariat untuk melihat distribusi frekuensi masising - masing karakteristik dan veriabel penelitian dan analisis bivariat untuk melihat perbedaan antar variabel pada kelompok bajo dan non bajo. Hasil analisis univariat dari karakteristik dan variabel penelitian ini dapat dilihat pada Tabel 1, sedangkan hasil analisis bivariat antara variabel pada masing - masing kelompok tampak pada Tabel 2.
Berdasarkan Tabel 1 diketahui bahwa sebagian besar umur ibu balita dengan gizi kurang baik pada suku bajo maupun non bajo adalah umur 20 - 25 tahun, 48,3\% untuk suku bajo dan 51,7\% untuk non bajo. Tingkat pendidikan yang paling banyak pada suku bajo adalah tamat SD (95\%), sedangkan suku non bajo tingkat pendidikan SMA/Sederajat $(81,6 \%)$ dan tingkat pendidikan akademi/perguruan tinggi hanya 2 orang (100\%). Pekerjaan ayah sebagian besar adalah nelayan, yaitu $73,3 \%$ untuk suku bajo dan $26,7 \%$ untuk suku non bajo. Pendapatan keluarga baik suku bajo maupun non bajo sebagian besar dengan kategori kurang yaitu 53,7\% untuk suku bajo dan 46,3\% untuk suku non bajo, sedangkan pendapatan keluarga cukup untuk suku bajo hanya 33,3\% dan non bajo 66,7\%. Pengetahuan ibu tentang gizi pada suku bajo sebanyak 81,8\% adalah kurang dan hanya hanya $28,6 \%$ kategori baik, berbeda dengan suku non bajo sebagian besar $(71,4 \%)$ kategori baik dan hanya hanya 18,2\% dengan kategori kurang. Faktor pola asuh sebagian besar baik pada suku bajo maupun non bajo menjukkan pola asuh yang negatif sebanyak 48,1\% pada suku bajo dan sebanyak 51,9\% pada suku non bajo. 
Tabel 1. Distribusi frekuensi responden kejadian gizi kurang berdasarkan karakteristik keluarga, balita dan variabel penelitian di wilayah pesisir Kecamatan Nambo Kota Kendari Tahun 2019.

\begin{tabular}{|c|c|c|c|c|c|c|}
\hline \multirow{3}{*}{ Variabel Penelitian } & \multicolumn{4}{|c|}{ Kejadian Gizi Kurang } & \multirow{2}{*}{\multicolumn{2}{|c|}{$\begin{array}{c}\text { Total } \\
(n=82)\end{array}$}} \\
\hline & \multicolumn{2}{|c|}{$\begin{array}{c}\text { Suku Bajo } \\
(\mathrm{n}=41)\end{array}$} & \multicolumn{2}{|c|}{$\begin{array}{c}\text { Suku Non Bajo } \\
(n=41)\end{array}$} & & \\
\hline & $\mathbf{N}$ & $\%$ & $\mathbf{N}$ & $\%$ & $\mathbf{N}$ & $\%$ \\
\hline \multicolumn{7}{|l|}{ Umur Ibu : } \\
\hline Umur 20 - 25 tahun & 14 & 48,3 & 15 & 51,7 & 29 & 100 \\
\hline Umur 26 - 30 tahun & 14 & 51,9 & 13 & 48,1 & 27 & 100 \\
\hline Umur 31 - 35 tahun & 10 & 71,4 & 4 & 28,6 & 14 & 100 \\
\hline Umur 36 - 40 tahun & 3 & 27,3 & 8 & 72,7 & 11 & 100 \\
\hline Umur $>40$ tahun & 0 & 0 & 1 & 100 & 1 & 100 \\
\hline \multicolumn{7}{|l|}{ Pendidikan Ibu: } \\
\hline SD & 20 & 95,2 & 1 & 4,8 & 21 & 100 \\
\hline SMP/Sederajat & 14 & 66,7 & 7 & 33,3 & 21 & 100 \\
\hline SMA/Sederajat & 7 & 18,4 & 31 & 81,6 & 38 & 100 \\
\hline Akademi/PT & 0 & 0 & 2 & 100 & 2 & 100 \\
\hline \multicolumn{7}{|l|}{ Pekerjaan Ayah: } \\
\hline Nelayan & 33 & 73,3 & 13 & 26,7 & 45 & 100 \\
\hline Swasta/Pedagang & 8 & 21,6 & 29 & 78,4 & 37 & 100 \\
\hline \multicolumn{7}{|l|}{$\begin{array}{l}\text { Pendapatan } \\
\text { Keluarga : }\end{array}$} \\
\hline Kurang & 36 & 53,7 & 31 & 46,3 & 67 & 100 \\
\hline Cukup & 5 & 33,3 & 15 & 66,7 & 15 & 100 \\
\hline \multicolumn{7}{|l|}{ Pengetahuan Gizi: } \\
\hline Kurang & 27 & 81,8 & 6 & 18,2 & 33 & 100 \\
\hline Baik & 14 & 28,6 & 35 & 71,4 & 49 & 100 \\
\hline \multicolumn{7}{|l|}{ Pola Asuh: } \\
\hline Negatif & 37 & 48,1 & 40 & 51,9 & 77 & 100 \\
\hline Positif & 4 & 80 & 1 & 20 & 5 & 100 \\
\hline Jumlah Responden & 41 & 100 & 41 & 100 & 82 & 100 \\
\hline
\end{tabular}

Berdasarkan hasil analisis dengan uji Independent Sample $t$ Test diperoleh nilai $p=$ 0,156 (tabel 2) yang berarti bahwa tidak ada perbedaan secara signifikan antara pendapatan keluarga suku bajo dan non bajodan rata -rata pendapatan keluarga suku bajo Rp.1.20.000 dan non bajo Rp.1.250.000. Selanjutnya pada tabel 2 diperoleh hasil untuk tingkat pengetahuan ibu tentang gizi dengan $p$ value $=0,001$ yang berarti bahwa ada perbedaan yang signifikan antara pengetahuan ibu tentang gizi pada suku bajo dan non bajo dengan nilai rata - rata untuk suku non bajo 7,15 dan nilai rata - rata suku bajo 4,65 yang berarti bahwa tingkat pengetahuan ibu 
balita non bajo lebih tinggi dari pada tingkat pengetahuan ibu balita pada suku bajo. Hasil uji Independent Sample t Test untuk faktor pola asuh diperoleh nilai $p$ value $=0,034$ yang berarti bahwa ada perbedaan yang signifikan antara pola asuh anak pada suku bajo dan non bajo dengan nilai rata - rata 12,38 pada suku bajo dan 13,62 pada suku non bajo yang berati bahwa rata - rata pola asuh anak pada suku non bajo lebih baik dari pada pola asuh ada suku bajo.

Tabel 2. Distribusi rata - rata perbedaan karakteristik keluarga dengan kejadian gizi kurang pada balita Suku Bajo dan Non Bajo di wilayah pesisir Kecamatan Nambo Kota Kendari tahun 2019

\begin{tabular}{lccc}
\hline \multicolumn{1}{c}{ Variabel Penelitian } & N & Mean & $\begin{array}{c}\text { Nilai } \\
\boldsymbol{p} \text { value }\end{array}$ \\
\hline Pendapatan Keluarga & & & \\
Suku Bajo & 41 & 1.120 .000 & 0,156 \\
Non Bajo & 41 & 1.250 .000 & \\
Pengetahuan Ibu & & & 0,001 \\
Suku Bajo & 41 & 4,65 & \\
Non Bajo & 41 & 7,15 & 0,034 \\
Pola Asuh & & & \\
Suku Bajo & 41 & 12,38 & \\
Non Bajo & 41 & 13,62 & \\
\hline
\end{tabular}

\section{PEMBAHASAN}

\section{Pendapatan keluarga}

Tingkat pendapatan keluarga baik suku bajo maupun non bajo tergolong kurang. Dari hasil analisis statistik dengan uji Independent Sample $t$ Test diperoleb nilai $p=$ 0,156. Hal ini menunjukan bahwa tidak ada perbedaan rata - rata pendapatan keluarga antara suku bajo dan non bajo. Ini terjadi karena secara georafis wilayah yang didiami oleh suku bajo dan non bajo memiliki batasan wilayah yang sama dan secara demogarfis dari sisi jenis pekerjaan atau pola pemenuhan kebutuhan baik suku bajo maupun suku non bajo adalah sama yaitu sebagai pelaut, pedagang asongan dan buruh sehingga pengahasilan atau pendapatan keluarga juga relatif sama. Hal ini mempengaruhi daya beli dan kemampuan keluarga dalam memenuhi kebutuhan hidupnya termasuk penyediaan pangan keluarga. Ketidak mampuan keluarga dalam menyediakan kebutuhan pangan keluarga ini dapat menimbulkan kerentanan terhadap permasalahan gizi kurang terutama pada kelompok balita. 
Peneltian ini sesuai dengan peneltian yang dilakukan oleh Fajria dan Darma (2016) yang menemukan bahwa pendapatan keluarga pada masyarakat bajo yang memiliki pekerjaan tetap sebagai nelayan (bagan kapal) memiliki ketahanan pangan yang tidak cukup sehingga keluarga rentan terhadap berbagai masalah termasuk masalah gizi. Dalam penelitiannya menemukan pula bahwa rata - rata masyarakat pesisir memiliki pekerjaan sebagai nelayan (Salim \& Darmawaty, 2016). Pendapatan keluarga merupakan salah satu faktor penting yang mempengaruhi ketahanan keluarga. Keluarga dengan penyedian atau pasokan pangan yang baik akan menghidari atau meminimalisir terjadinya kerawanan pangan dan persoalan gizi dalam keluarga(Banjarnegara, 2011).

\section{Pengetahuan ibu}

Hasil penelitian menunjukkan bahwa nilai $p$ value $=0,001<$ nilai $\alpha=0,05$ yang berarti bahwa ada perbedaan yang signifikan antara pengetahuan ibu balita pada suku bajo dan non bajo dengan kejadian gizi kurang. Ini berarti bahwa rata - rata pengetahuan ibu balita non bajo tingkat pengetahuannya lebih tinggi dibanding dengan ibu balita dari suku bajo. Hal ini dapat terjadi karena beberapa alasan seperti faktor tingkat pendidikan dari kedua kelompok juga sedikit berbeda, dimana pada kelompok suku bajo mayoritas atau 20 responden $(95,2 \%)$ hanya tamatan SD sedangkan pada kelompok suku non bajo sebagian besar atau 31 responden $(81,6 \%)$ merupakan lulusan dari SMA/sederajat.

Pengetahuan adalah hasil dari "tahu" dan ini terjadi setelah orang melakukan penginderaan terhadap suatu objek tertentu. (Notoatmodjo, 2014). Pengetahuan muncul ketika seseorang menggunakan inderanya untuk menggali benda atau kejadian tertentu yang belum pernah dilihat atau dirasakan sebelumnya (Ikawati \& Wijayanti, 2014). Seperti dikatakan oleh Notoatmodjo bahwa salah satu yang mempengaruhi tingkat pengetahuan seseorang adalah tingkat pendidikannya (Notoatmodjo, 2014).

Hasil penelitian ini sesuai dengan penelitian yang dilakukan oleh Rahma AC \& Nadhira (2016) yang menemukan ada perbedaan tingkat pengetahuan orang tua (ibu balita) antara dua kelompok balita yang mengalami permasalahan gizi kurang (Rahma \& Nadhiroh, 2017). Penelitian yang dilakukan oleh Lailatul dan Ni'mah menemukan hal yang berbeda dari penelitian ini yaitu dalam penelitian mereka menemukan bahwa tidak ada 
perbedaan antara tingkat pengetahuan ibu dengan status gizi termasuk gizi kurang dan stunting pada balita (Lailatul \& Ni'mah., 2015).

\section{Pola asuh}

Hasil analisis analisis statistik dengan uji Independent Sample $t$ Test diperoleh hasil bahwa nilai $\mathrm{p}$ velue $=0,034$, berarti pada alpa 5\% ada perbedaan yang signifikan antara pola asuh pada suku bajo dengan pola asuh pada suku non bajo khususnya kaitannya dengan masalah gizi kurang. Data ini mengandung makna bahwa pola asuh pada suku non bajo sedikit lebih baik dari pada pola asuh pada suku bajo dengan kejadian gizi kurang pada masyarakat pesisir khusus pada anak balita diwilayah pesisir Kecamatan Nambo Kota Kendari.

Pola asuh balita adalah kemampuan keluarga dan masyarakat untuk menyediakan waktu, perhatian dan dukungan terhadap anak agar dapat tumbuh dengan sebaik-baiknya seara fisik, mental, dan sosial. Pola pengasuhan anak berupa sikap perlakuan ibu dalam hal kedekatannya dengan anak, memberikan makanan, merawat, menjaga kesehatan dan kebersihan, memberikan kasih sayang, dan sebagainya. Akan tetapi hasil penelitian ini tidak sesuai dengan teori diatas karena walaupun pola asuh ibunya cukup tetapi balita menderita penyakit infeksis ehingga balita kesulitan mencerna dan menelan makanan serta penyerapan zat gizi dalam tubuh terganggu (Tiara Dwi Pratiwi, 2016).

Penelitian ini sesuai dengan penelitian dari Aramico yang menemukan ada hubungan antara pola asuh dengan kejadian gizi kurang pada balita dengan nilai $\mathrm{p}=$ 0,001.Dari hasil analisis statistikanya pada uji silang diperoleh bahwa sebagian besar rsepondennya memiliki pola asuh yang kurang baik, hal yang sama dengan penelitian ini. Dalam penelitian Aramico juga membandingkan antara dua kelompok sampel yaitu kelompok stunting dan kelompok normal dan penelitian ini juga membandingkan dua kelompok yaitu kelompok suku bajo dan non bajo. Hal ini memungkin adanya kesamaan hasil dari kedua penelitian ini (Aramico, Sudargo, \& Susilo, 2016).

Diana dalam penelitiannya menemukan hal yang berbeda dengan penelitian ini, dimana dalam penelitiannya menemukan bahwa tidak ada hubungan antara pola asuh orang tua dengan gizi kurang pada balita dan pola asuh orang bukan merupakan faktor terjadinya gizi kurang pada balita. Dalam penelitian Diana juga 
tidak membandingkan antara suku tertentu dengan kejadian gizi kurang pada balit (Diana, 2006). Hal yang berbeda dengan rseponden dari penelitian ini dimana seluruh responden khususnya pada kelompok suku bajo merupakan ibu rumah tangga yang tidak bekerja. Ini bisa menjadi salah satu sisi perbedaan dari penelitian ini (Diana, 2006).

\section{KESIMPULAN}

Penelitian ini menemukan bahwa ada perbedaan antara pengetahuan ibu dan pola asuh dengan gizi kurang pada suku bajo dan non bajo. Rata - rata pengetahuan ibu suku non bajo lebih baik dibandingkan dengan suku bajo terkait dengan maslah gizi kurang, demikian juga pola asuh suku non bajo sedikit lebih baik dari pada pola asuh suku bajo. Dari sisi pendapatan keluarga tidak ada perbedaan antara suku bajo dan non bajo dengan gizi kurang di wilayah pesisir Kecamatan Nambo Kota Kendari. Rata - rata pendapatan keluarga baik suku bajo maupun non bajo berkisar antara Rp1.120.000 - Rp.1.250.000 yang secara statistik dianggap sama/tidak ada perbedaan.

\section{SARAN}

Saran untuk penelitian selanjutnya agar melihat faktor risiko terjadinya gizi kurang pada balita di wilayah pesisir dengan metode penelitian yang berbeda.

\section{REFERENSI}

Aramico, B., Sudargo, T., \& Susilo, J. (2016). Hubungan sosial ekonomi, pola asuh, pola makan dengan stunting pada siswa sekolah dasar di Kecamatan Lut Tawar, Kabupaten Aceh Tengah. Jurnal Gizi Dan Dietetik Indonesia (Indonesian Journal of Nutrition and Dietetics). https://doi.org/10.21927/ijnd.2013. 1(3).121-130

Banjarnegara, D. I. K. (2011). Pangan Serta Kaitannya Dengan Status Giri Anak Balita. 6(1), 51-58.

Diana, F. M. (2006). Hubungan Pola Asuh Dengan Status Gizi Anak Batita Di Kecamatan Kuranji Kelurahan Pasar Ambacang Kota Padang Tahun 2004. Jurnal Kesehatan Masyarakat, 19-23.

Dinas Kesehatan Kota Kendari,. (2017). Profil Dinas Kesehatan Kota Kendari. Kendari.

Harmiyanti, Rahman Nurdin, Fauziah Lilis. (2017). Faktor Risiko Kejadian Gizi Kurang pada Balita Usia 24-59 Bulan Di Kelurahan Taipa Kota Palu. Jurnal Ilmiah Kedokteran. Katalog: 1102001.7202054. (n.d.).

Kecamatan Nambo (2019) Profil Kecamatan Nambo, Kendari.

Lailatul, M., \& Ni'mah., C. (2015). Hubungan Tingkat Pendidikan, Tingkat Pengetahuan dan Pola Asuh Ibu dengan Wasting dan Stunting pada Balita Keluarga Miskin. Media Giri Indonesia, 10(2015), 84-90. https://doi.org/Vol. 10, No. 1 Januari-Juni 2015: hlm. 84-90.

Lorensa, C., Permana, G. I., Mia, I. G., Leiden, N. A. O., Lestari, N. A., Pribawa, R., ... Lestari, L. (2018). Hubungan Status Gizi (Berat Badan Menurut Umur) Terhadap Kejadian 
Infeksi Saluran Pernafasan Akut (Ispa) Pada Balita. Jurnal Berkala Kesehatan.

https://doi.org/10.20527/jbk.v3i1.4 850.

Nasir, Abd. Murith, Abdul. deputri, M. . (2011). Buku ajar Metodologi Penelitian Kesehatan konsep Pembuatan Karya Tulis dan Thesis untuk Mahasiswa Kesehatan. In Numed. https://doi.org/10.1016/ j.pdj.2014.07.001

Notoatmodjo, 2014. (2014). Konsep Pengetahuan, dan Sikap. Cell. https://doi.org/10.1016/j.cell.2009. 01.043

Rahma, A. C., \& Nadhiroh, S. R. (2017). Perbedaan Sosial Ekonomi Dan Pengetahuan Gizi Ibu Balita Gizi
Kurang Dan Gizi Normal. Media Giæi Indonesia, 11(1), 55. https://doi.org/10.20473/mgi.v11i1 $.55-60$

Salim, F. D., \& Darmawaty, D. (2016). Kajian Ketahanan Pangan Rumah Tangga Nelayan Buruh Di Desa Bajo Sangkuang Kabupaten Halmahera Selatan. Jurnal Sosial Ekonomi Kelautan Dan Perikanan, 11(1), 121. https://doi.org/ 10.15578 / jsekp.v11i1.3177

Tiara Dwi Pratiwi. (2016). Hubungan pola asuh ibu dengan status gizi balita di wilayah kerja Puskesmas Belimbing Kota Padang. Jurnal Kesehatan Andalas. https:// doi.org/ 10.1080/ 19325037.2013.767734 